\title{
Planning through a Prism of Individual Interests: Historical Events Defining the Area of Bratislava's Former Key Industrial Zone*
}

\author{
Nina Bartošová
}

vol. 8, 2019, 2, pp. 39-62

DOI: https://doi.org/10.33542/MAD2019-2-03

This study aims to uncover the background of a former key industrial zone of Bratislava that was developed not only in proximity to the Danube, but also relatively close to the historical centre. It was flood area at the time, considered peripheral with an unfavourable reputation, separated by railway lines from the city, with winds blowing southeast - away from populated areas - thus making it a seemingly ideal place for industry. However, a current perspective - when just a fraction of historical buildings remain, and are surrounded by new high-rise structures, and with society familiar with industrial contamination - offers an opportunity to look more closely at past planning processes, as they might be more relevant to present-day decision-making than we might have thought.

Keywords: Industry. Bratislava. Heritage. Planning. Development.

\section{Introduction}

Prešporok (Pressburg in German, Pozsony in Hungarian), as the city of Bratislava was called until $1919,{ }^{1}$ used to be one of the most important industrial centres of the Hungarian kingdom of the Austro-Hungarian Empire - a fact that is not immediately apparent because of the small number of industrial structures preserved up to the present. Comparing historical documentation and period images with the current situation naturally brings the attention primarily toward the questionable processes that led to the destruction of buildings that were once a source of pride in the city, as a symbol of its progress. Although the situation is far from ideal, in terms of both industrial and modern heritage, a number of experts have already addressed the issues of insufficient protection for more recent and less traditional heritage. ${ }^{2}$ Though some might argue that little of the industrial heritage is left to protect, there are still some structures deserving attention and proper evaluation, and therefore further research.

However, this study focuses on a different issue: the analysis of historical events that led to development of a key industrial zone in the area of the former Mühlau (Nivy), in spite of its relative proximity to the historical centre (Figure 1). The research has been based on the premise that the recent and oft-criticised development in this area can, paradoxically, be seen as parallel to the industrial zone's previous development. In addition, a deeper understanding of those events might serve not as an apology for current development, but rather a guide of what not to ignore in planning, which could be helpful for future development in the adjacent Winter Harbour area.

This article represents research of the Faculty of Architecture at Slovak University of Technology in Bratislava (STU) funded by VEGA grants no. 1/0444/17 Tradition and Innovation in Architecture as a Phenomenon of the Long Century, and no. 2/0074/17 Unintended City: Architectural and Town-Planning Conceptions of the 19th and 20th century in the Urban Structure of Bratislava.

1 For consistency we will use the term "Pressburg" until 1919 and "Bratislava" from 1919 in the remaining parts of this article, except when citing from period literature.

2 A recent article by ŠUŠKA, Historické priemyselné štruktúry, 241-262, see also: ŠULCOVÁ, Historický industriál. 

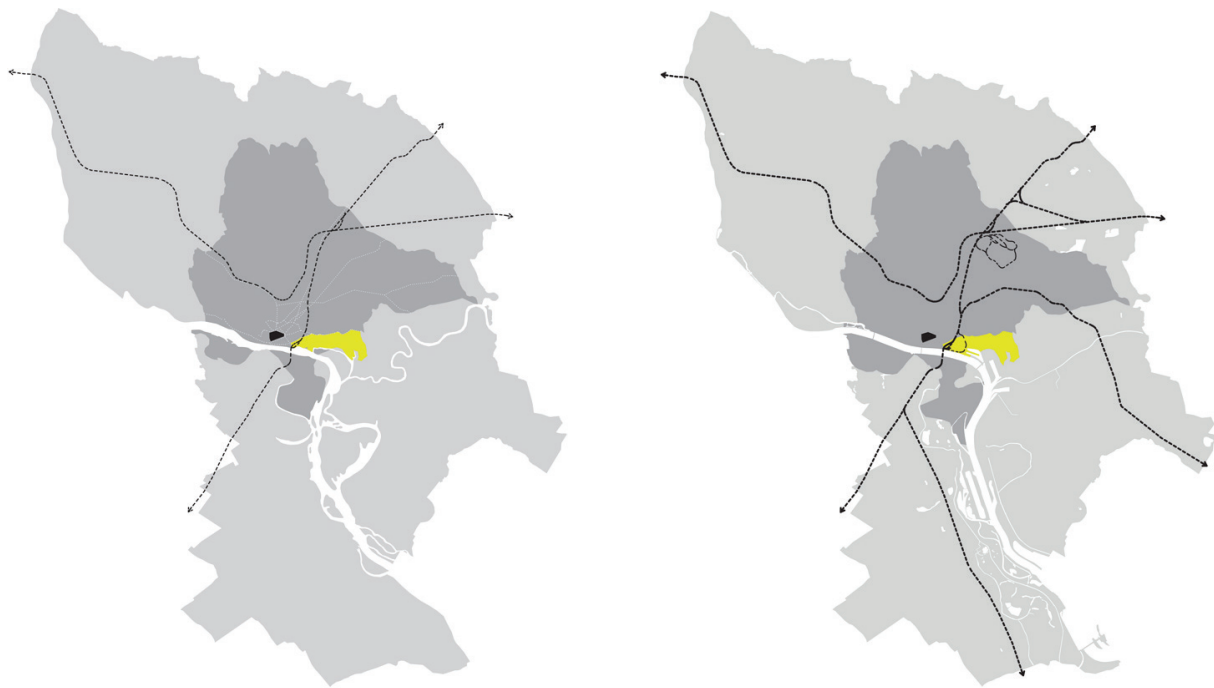

Figure 1: The area of the former Mühlau (Nivy) in yellow and its relative closeness to the historical city centre (black), and the area of Prešporok at the turn of the 20th century (darker grey). The dotted lines represent the railway connection, and the Danube is left in white. The light grey colour represents today's area of Bratislava.

For our research, the most important information was gathered via careful study, comparison and analysis of historical maps and plans. The majority of those are in the possession of the Bratislava City Archives, but have not been accessible for a number of years, due to problems of storage. Therefore, except for a small selection of plans made available for a very short time, we depended heavily on other sources, particularly on period publications, some of which are available on the internet. Although the historian Viera Obuchová mentions that some excellent research into our study's focus area was done by the Municipal Institute of Monument Protection (Slovak abbreviation: MÚOP) in the 1980s, it is nowhere to be found. ${ }^{3}$

The topic of this study is the continuation of previously published research, and reflects mainly on studies by experts from the Slovak Academy of Science (Department of Architecture, Institute of History) among others. Information about opinions that were generally prevalent in the past has been obtained through examination of the period press (journals and magazines in German, Slovak and Czech) and from archival documents.

\section{Delayed Industrialisation}

Although Pressburg appeared to be a flourishing industrial town at the turn of the twentieth century, there was a significant delay in industrialisation compared to other places in Europe. It was not until the last quarter of the nineteenth century that a more noteworthy number of industrial enterprises appeared in the town,

3 OBUCHOVÁ, Najstaršie továrne Bratislavy, 21. 
after the Austro-Hungarian Compromise (1867) and the abolition of guilds (1872) ${ }^{4}$ brought more favourable conditions for the development of industry. ${ }^{5}$ Apart from the political and related economic situation that caused this delay, the local industry faced challenges from other disadvantages rooted deeper in history, in the early manufacturing period (1725 - 1825). Progress in important industrial centres around Europe was based on previous successes in manufacturing, existing knowledge concerning production, expert skills, and a functioning economic structure that could be further developed.

Although manufactured production had been present in Pressburg for some time, it had also been delayed. During the reign of Maria Theresa it was "explicitly emphasised that Hungary should remain a non-industrial, agrarian country - a supplier of raw materials to other countries - while other of the empire's countries should be developed, building on the development of crafts to date". ${ }^{6}$ This was based on the fear that Hungarian industry could potentially create undesirable competition for the Austrian lands. Later, this opinion changed, and the situation improved even more during the reign of her son, Joseph II, who encouraged the development of manufacturing in Slovakia and the rest of Hungary. ${ }^{7}$ We can argue that one of the consequences of the above-mentioned circumstances was that the development of industry was not taken seriously enough to be underpinned by city planning before industrial enterprises started to build their first factories.

\section{Growth of Industry}

In addition to the aforementioned historical turning points that allowed industry to develop in Hungary in the last quarter of the nineteenth century, legislative measures "industrial laws" - enacted between 1881 to 1907 were important too. ${ }^{8}$ From 1881, the law promised tax advantages for industrial enterprises that established business in the country. This support for Hungarian industry was meant to protect it against the more developed Austrian and Czech industries. In reality, it was the social class of landowners who pushed their interests through, hence of all the tax advantages just a small proportion went to existing factories, an even smaller amount to new factories, and the majority went to support landowners and their production (distilleries). ${ }^{9}$ Austria, on the other hand, defended its own interests, and succeeded in ensuring that support was not given to any types of production that already existed within its domestic industry.

It is necessary to stress that all the important enterprises established in Pressburg were mostly in the hands of Hungarian or Austrian investors, as well as some investors outside of Austria-Hungary. The Slovak bourgeoisie was not able to compete with them, and even the state was against the concentration of Slovak capital, suggesting

\footnotetext{
4 Modern Slovakia, along with the rest of the Hungarian area, was an exception within Europe, while guilds and manufacturers had equal rights - a situation that inhibited the development of the latter. ŠPIESZ, Manufaktúrne obdobie na Slovensku, 71.

5 HALLON, Firma Pittel a Brausewetter, 11.

6 ŠPIESZ, Manufaktúrne obdobie, 48.

7 ŠPIESZ, Manufaktúrne obdobie, 70.

8 HALLON, Význam industrializačnej politiky, 121-148.

9 BIANCHI, Zákonodarstvo a vývoj priemyslu, 127.
} 
Slovak financial enterprises were dangerous for the state unity of Hungary. ${ }^{10}$ Pressburg, on the border of today's Hungary and Austria, close to both Vienna and Budapest, with the Danube River connecting all three cities, became an attractive place for business. Nevertheless, the city did not fully benefit from the advantages the Danube offered until important regulation of the river took place between the years 1886 and $1896 .{ }^{11}$

Railway connection was equally important for the bloom of industry. The Central Hungarian Railway received a concession under advantageous conditions back in 1844, which allowed construction of a steam railway connection from Marchegg through Pressburg to Budapest. This line started operating in $1848 .^{12}$ The already existing horsedrawn railway, which had begun operating in 1840, "envisaged only an acceleration of the transport of agricultural products to Pressburg and via the Pressburg - MarcheggVienna line". ${ }^{13}$ However, until the Franz Joseph Bridge (designed by engineer Francois de Sales Cathry and constructed by the chief city engineer Anton Sendlein) opened in 1891, Pressburg's only connection to the right bank was a pontoon bridge, which dated from 1829. ${ }^{14}$ The new bridge's construction was realised as a part of the railway project connecting Pressburg to Szombathely. Although discussions regarding construction of a permanent bridge over the Danube dated back to 1877 , the work, financed by the Hungarian government, did not begin until April $1889 . .^{15}$ The industrial laws from 1881 and 1888 further simplified the legal processes of railway construction.

With some exceptions, most industrial enterprises were located in proximity to the river and railways. ${ }^{16}$ The oldest available maps show the first factories were concentrated between the rails of a former horse-drawn railway (along today's Karadžičova Street) and the Danube River. ${ }^{17}$ This area, called Mühlau in German or Malom Liget in Hungarian, is today part of the Nivy quarter (part of Ružinov borough, Bratislava II), and had been previously characterised by fields, meadows and groves. There were a number of mills, and later a toll house, a tavern and warehouses. ${ }^{18}$ A map, dated 1873, marks among the first industrial enterprises a cloth factory, a paper factory and a charcoal factory (Spodium Fabrik). ${ }^{19}$ Könyöki's guide, published in 1873, mentions a sugar

10 Of the 100 tax-reliefs, 49 applied to upper Hungary (the territory of Slovakia), but only 6 to Bratislava (less than Dolný Kubín, Banská Bystrica, Košice or Levoča). BIANCHI, Zákonodarstvo a vývoj priemyslu, 130-131.

11 "The Danube by Bratislava was regulated in three phases, with the earliest works dating back to 1772-1780. The second stage occurred between 1832 and 1834, followed by a third phase of systematic river channelising (1886-1896)." (PIŠÚT, Využitie historických krajinomalieb, 173-194). Regulation between the years 1886 and 1896 was realised according to the plans of Italian engineer Enea Grazioso Lanfranconi (BARTOŠíkOVÁ, Prístav v Bratislave, 30).

12 The first train with a steam locomotive arrived in Bratislava on 20 August 1848 (KUBÁČEK, Uhorská centrálna železnica, 35-36).

13 SZOJKA, Bratislava a železnice, 15.

14 SZOJKA, Bratislava a železnice, 104.

15 KAČíREK - TIŠLIAR, Petržalka do roku 1918, 55.

16 One of the exceptions was Grüneberg's brush factory in Blumental, established already in 1866, which developed from a brush manufacturer (RAINER - ULREICH, Karpatendeutsches Biographisches Lexikon), though the historian Viera Obuchová dates the origins of the factory to 1872 (OBUCHOVÁ, Priemyselná Bratislava, 168).

17 The Považská railway used rails of the former horse-drawn railway, and also horse-drawn passenger wagons called "Tramway-Züge" (SZOJKA, Bratislava a železnice, 38).

18 HORVÁTH, Bratislavský topografický lexikón, 189.

19 Staré mapy. 
refinery owned by Mr Geyduschek and Mr Pollak's Spodium Fabrik in Mühlau. There was a wine cellar and bottling plant owned by Palugyay and Sons near the train station; a potato-sugar factory, a candied fruit factor, a champagne factory and a cigar factory in Blumental; and also a malt factory. ${ }^{20}$ Another map, dated 1895 (Figure 2), marks a cloth factory (Posztógyár, no. 42), a canvas factory for linen and jute goods also known as Klinger's factory (Vitorlavászon Len es Jutta-áruk gyára, no. 43), and a charcoal (activated carbon) factory (Spodium Fabrik in German, Csontszén Gyár in Hungarian, no. 44) in Mühlau. ${ }^{21}$

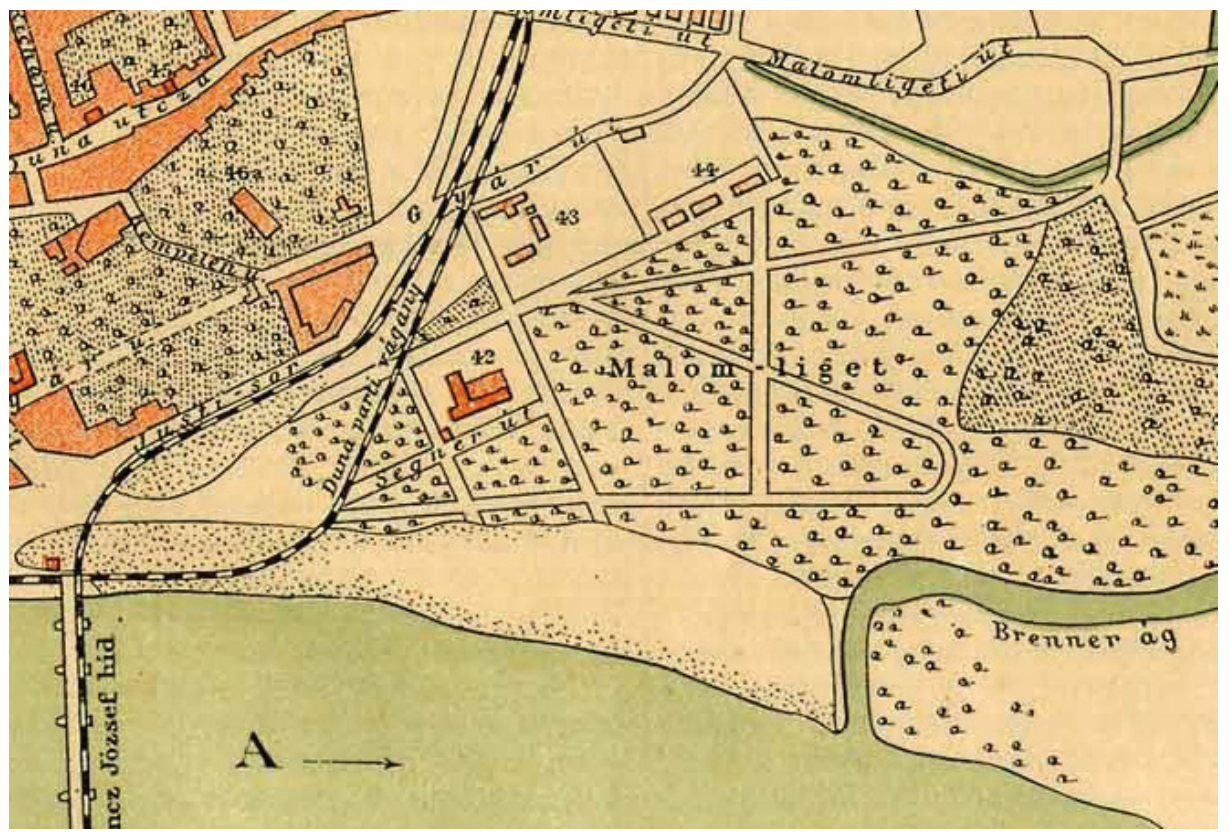

Figure 2: This map, dated 1895, shows a cloth factory (Posztógyár, no. 42), a canvas factory for linen and jute goods (Vitorlavászon Len es jutta-áruk gyára, no. 43) and a charcoal factory, i.e., an activated carbon factory (Spodium Fabrik, no. 44). Source: Pallas Lexikon, digitized by Arcanum Database Ltd for the Hungarian Digital Archive of Pictures, https://dka.oszk.hu/000600/000626

There were also other factories in areas further from the historical town centre, such as Kühmayer's factory, built on the site of the former seventh mill in 1868; the bullet factory of J. Roth (1870) in the area of Patrónka, northwest from the centre; the Stein Brewery (1872) and Ludwig's Mill (1880), near the former horse-drawn railway station; and the explosives factory Dynamit-Nobel (1873) far to the northeast. Looking further afield, the Stollwerck factory (1895), the Siemens factory, the Thread factory "Cvernovka" (1901), and the Danubius factory (1907) were not as concentrated within a compact area as was the case for factories located in the Mühlau area. Most of the

20 KÖNYÖKI, Kleiner Wegweiser.

21 There was also a tobacco factory (M. kir. dohánygyár, no. 73) and Grüneberg's brush factory (Grüneberg-féle kefegyár, no. 63), indicated on the map that is partially displayed in Figure 2. 
important factory complexes were built by construction companies either of the Feigler family or Pittel and Brausewetter, founded in the 1970s. ${ }^{22}$

\section{Mühlau - the Ideal Place for the Development of Industry?}

The Mühlau area did not become an industrial quarter as a result of progressive planning. It was rather a consequence of various independent decisions made by the city, with no detailed idea of how the city should evolve in the future. In the period when the first industrial factory areas were established in the vicinity of Pressburg, the city did not have a regulatory plan, and construction was the result of individual decisions made by the Chamber of Industry and the city. The Danube River had been regulated only to a certain extent - along the south bank of the river - while the area that is now occupied by the Winter Harbour was still a shore of the Brenner Island. ${ }^{23}$ The regulation that took place at the end of the nineteenth century significantly lowered the danger of flooding, and in its wake the number of factories in the Mühlau area increased. But even before that, the decision to develop industry in Mühlau seemed quite natural, in spite of its relative proximity to the historical centre, as the risk of floods made it inappropriate for urban expansion. ${ }^{24}$ According an article published in Pressburger Zeitung in 1891, in general there was a good deal of uncritical enthusiasm toward industry, as the city was developing into "a beautiful Hungarian industrial emporium". ${ }^{25}$

However, opinions over Mühlau's suitability were not as homogenous as may appear at first glance, as illustrated by a number of daily press articles published in the $1890 \mathrm{~s}$. There was quite a strong ongoing debate in a number of articles published in the local German-language newspaper Pressburger Zeitung throughout 1894. Various authors argued over whether the area, soon to become the city's key industrial zone, would not be better used as a park. The discussion started with the efforts of the industrialist Heinrich Klinger, owner of a factory for linen and jute goods, to build some 30 workers' apartments on a site that he bought from the city in Mühlau, on the edge of the area "bounded by the path leading past the jute factory directly to the Danube and, on the other side, by Szegnergasse". ${ }^{26}$ According to a later published article, Klinger's planned constructions were not approved by the city, which insisted that this inundation area should be used as a park - an idea criticised by its author. ${ }^{27}$

A follow-up article forwards the argument that the most rational use for the area was to designate it for industry because of its proximity to the river, railway connections and the adjacent territory where the Winter Harbour and trading port were being constructed, and because the prevailing wind direction would blow smoke from the factories away from the city. The author ironically states that a park would be more

22 POHANIČINOVÁ, Tvorba Feiglerovcov, 110-115. See also: POHANIČOVÁ - BUDAY, Storočie Feiglerovcov, 116-131.

23 The first regulation of the Danube River had happened during the reign of Maria Theresa, concerning the Isle of Pečeň (nem. Pötschen/ mad'. Pö(c)csen). More in: PIŠÚT, Zmena bratislavského Dunaja, 103-113.

24 Information published in Pressburger Zeitung on 4 January 1883 (Tagesneuigkeiten, 1) gives information about a significant flood that left a large area inundated.

25 Erasmus Hafenlauf stellt darüber Betrachtungen an, wie spät oft manchmal die Erleuchtung kommt. In: Pressburger Zeitung, 17. 5. 1891, vol. 128, no. 135, p. 5.

26 Neue Arbeiterhäuser. In: Pressburger Zeitung, 14. 1. 1894, vol. 131, no. 12, p. 2.

27 Zum Bau von Arbeiterwohnungen in der Mühlau. In: Pressburger Zeitung, 14. 11. 1894, vol. 131, no. 312, p. 2. 
a "delightful hideaway for the homeless and vagabonds, where one should never go unaccompanied, or at least never without a good stick". At that time, the General Assembly had apparently already offered the sites to industrialists at reasonable prices as good places to build factories: "One cannot overturn such important decisions in order to obtain a few dozen crippled trees as an appendage of very questionable value".28

A similar opinion was presented in an article from November 1894: "A year ago, nobody would have dreamed that any opposition could arise against the use of areas of Mühlau", claiming that everyone must consider it the most suitable place for factories or really the only place. "Even if one could think of Blumental, that area did not have a sewage system and the land is much more expensive. The train connection and water connection were not available either." For workers' dwellings, the author proposes an area near Schulpe's colony called Pöllnmauth (today's Žilinská), where earlier vineyards had been destroyed by the phylloxera blight. These areas would be healthier and more appropriate for residential houses than "the damp mosquito-filled area of Mühlau, where today's young generation catches frogs in the swamp". To conclude, the author hopes for the "growth of a cleverer generation" who would not think of building houses in Mühlau, hoping the parcelling of the area for factories would "quietly" continue according to the city's original plans. ${ }^{29}$ According to the line of the Danube River as pictured on the map from 1895 (Figure 2), this was still before both its regulation $(1886-1896)$ and the construction of the Winter Harbour, which started at the end of the nineteenth century in the area of Brenner Island. ${ }^{30}$

The period when these discussions about Mühlau's future were appearing in the press was before the foundation of the Apollo Oil Refinery, in the area bounded today by the streets Mlynské nivy (from the north), Dostojevského rad and Karadžičova (from the east), Košická (from the west) and Landererova (from the south). The Apollo Oil Refinery not only occupied the largest site, but its position so close to the historic centre today seems rather surprising.

The refinery was established in 1895, and production started in December of that year. ${ }^{31}$ As can be seen on maps from the beginning of the 20 th century (Figures 3,4 ), the factory premises occupied a significant area to the south of Klinger's factory and the charcoal factory. ${ }^{32}$ On the map, north of those factories, along Továrenská Street at a corner position, is a cable factory, established by the industrialist Egon Bondy in 1894, which originally produced clock springs and then cables.

28 Von der "schönen" Mühlau. In: Pressburger Zeitung, 24. 11. 1894, vol. 131, no. 322, p. 2.

29 Noch einmal die "liebliche" Mühlau. In: Pressburger Zeitung, 25. 11. 1894, vol. 131, no. 323, p. 2.

30 See also: BARTOŠíkOVÁ, Prístav v Bratislave.

31 Photocopies of official documents are available at the Slovnaft Archive. See also: STANISLAV, Rafinéria Apollo, 14; Československá republika: Bratislava, 135.

32 AMB, Zbierka máp a plánov. 


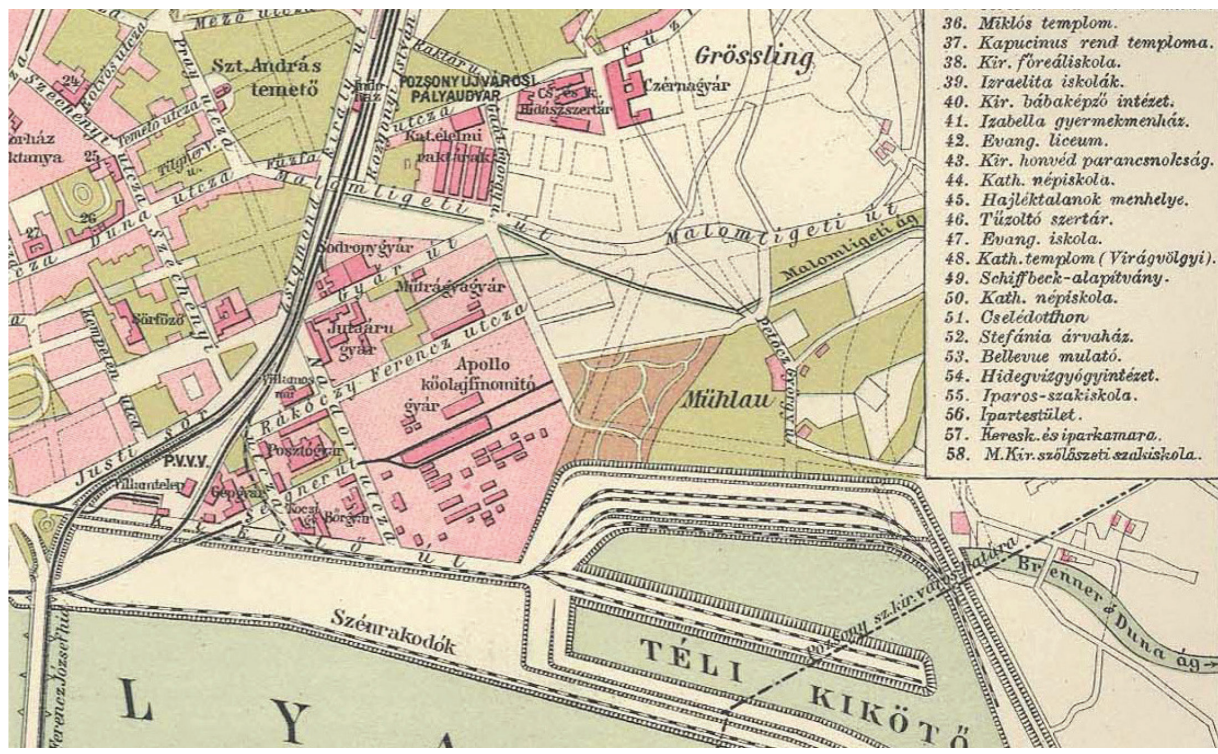

Figure 3: This map, from the beginning of the 20th century, shows our focus area after the regulation of the Danube River. The Apollo Oil Refinery already occupies the largest area (and later it also took over the area of Klinger's factory). We can also see a fertilizer factory (mútrágyagyár) on the north-east of Apollo, and the city electrical works on the north-west (Városi villamos múvek). Source: BOROVSZKY. Magyarország vármegyéi és városai, digitized by Arcanum Database Ltd for the Hungarian Digital Archive of Pictures, http://mek.oszk.hu/09500/09536/html/0017/7.html

Quite surprisingly, while there were several articles discussing whether Klinger's workers' houses were appropriate for the area, we were not able to find a single article questioning construction of an oil refinery so close to the centre. It is possible that the public were ill-informed about its construction in advance, as the decision regarding its establishment had been made in Budapest, and consequently an area in Mühlau that belonged to the city was sold to the company for that purpose. ${ }^{33}$ The oldest mentions we could find in the local press were a brief note providing information about the Apollo joint stock bid, which appeared in the newspaper Nyugatmagyarországi hiradó on the 8 August 1895, the year the factory was established; and an article reporting on an administrative inspection in the presence of the city's mayor, Gustav Dröxler, two years later. ${ }^{34}$ An article published two years later in Pressburger Zeitung, gave information on a report by the Building Commission regarding the installation of odour-prevention devices that were reportedly working properly. ${ }^{35}$ Another article from the same year contained details of an excursion by Pressburg Academy of Commerce

33 According to a promulgation from 13 February 1895 signed by the mayor of the city, Gustav Dröxler, the area was sold to Arpád Spitz, Budapest resident and company general director (IŽO, Dejiny Apolo rafinérie, 264).

34 Hirdetmény. In: Nyugatmagyarországi hiradó, 8. 8. 1895, vol. 8, no. 181, p. 2.

35 Der Schluss der vorgestrigen Repräsentanten-Sitzung. In: Pressburger Zeitung, 5. 11. 1897, vol. 134, no. 306, p. 2. 


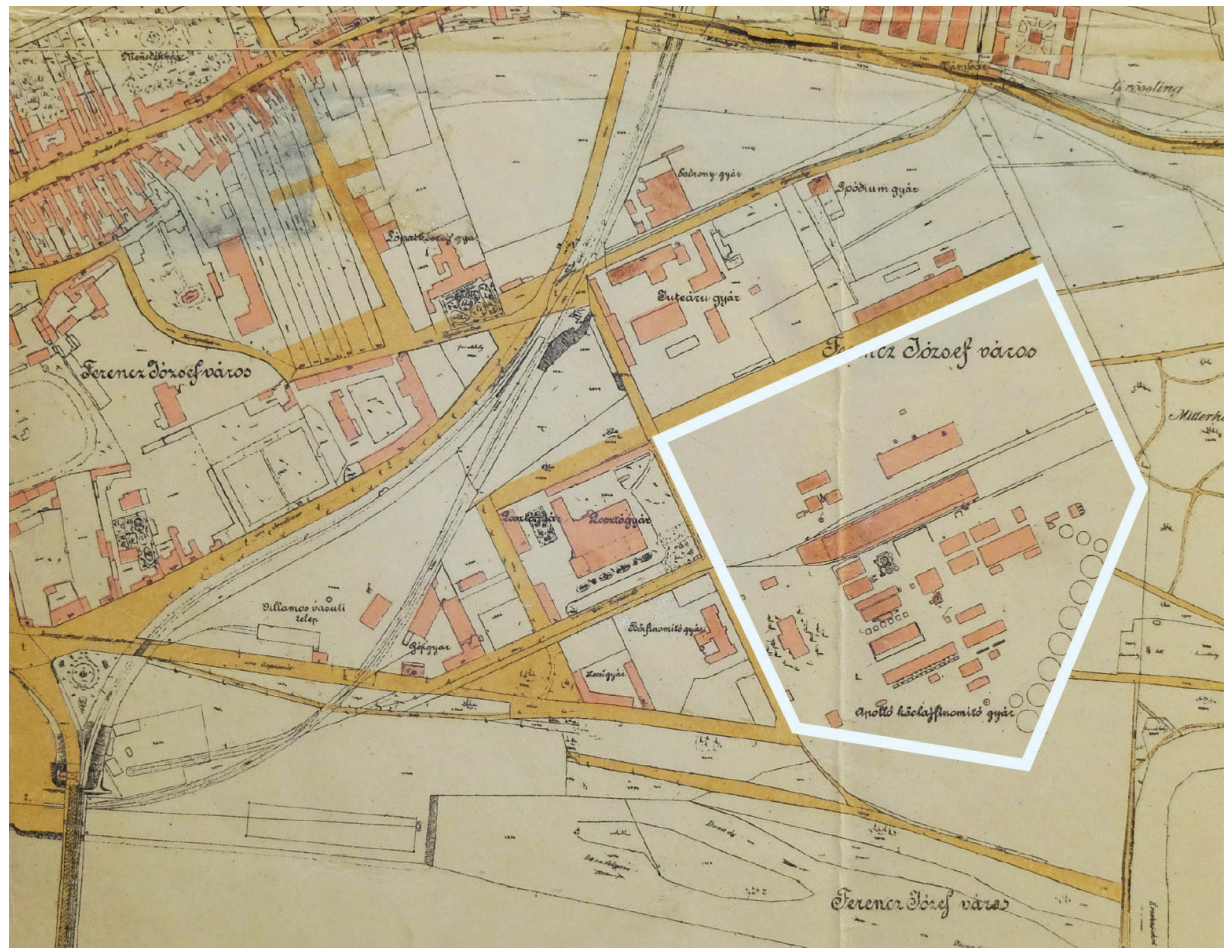

Figure 4: Highlighted is the area of the Apollo Oil Refinery drawn on a map base from 1994. Source: AMB, Zbierka máp a plánov (Collection of Maps and Plans), no. 1052.

students, who visited a number of the larger factories in the town, including the Apollo Oil refinery, where they learned about production processes. ${ }^{36}$

The only documented opposition to the Apollo Oil Refinery is in the form of complaints by the owners of the adjacent industrial areas, which we found in the archives of Slovnaft a.s., the enterprise that took over Apollo after the Second World War. Opposition was raised after Apollo sought permission to construct a new plant in 1936. To those complaints regarding bad odour, noise and danger, Apollo responded that the Bratislava had no regulation regarding the construction industrial buildings, and the authorities did not prescribe any minimum distance that had to be abided by. Apollo concluded that the new plant, designed "according to the newest technological progress" for extracting local mineral products, was of national interest, as its products would no longer have to be imported from abroad. ${ }^{37}$

It was not until 1900 that an article appeared in the Pressburger Presse entitled "Die Schornstein-Jagd" (chimney-hunting) openly criticising the way the city approached industrial development. Though it considered the rational pursuit of industrial development and economic independence to be praiseworthy, it found the

36 A pozsonyi kereskedelmi akadémia. In: Nyugatmagyarországi hiradó, 6. 10. 1897, vol. X, no. 228, p. 3.

37 Slovnaft Archive, Municipal Notary Office, document from 1936. 
circumstances in Pressburg extreme. It went beyond questioning the extent to which industrialisation in the city had progressed, suggesting that Pressburg would never become an industrial city like, for example, Brno even if "a hundred factories are built here, because they will always have only all the downsides and disadvantages but very few of the advantages of those factories, built with foreign money and whose owners live abroad and consume their income there". ${ }^{38}$

The main criticism the article's author raises is that Hungary was being used for cheap labour, rather than being given the chance to acquire the necessary capabilities on its own. The author claimed that the industrial movement brought "thousands of foreign elements into the country" which, in the end, "brings us into even greater dependence on foreign countries". In addition, he questions whether Hungarian industry, "or rather 'industry in Hungary' (because we will not have a 'Hungarian' industry for a long time yet), can win a place among the international competition. Therefore, we can only expect our salvation from a gradual, long-established industrial movement of the people, schools and society." 39 On top of that, the article specifically criticises the development of industry in Mühlau and the "total lack of plans" relating to the expansion of the city that allowed a factory district to arise so close to the city centre, a situation that risks undermining the sanitary conditions of Pressburg, something that should be "seriously feared". 40

\section{Toward Regulation of Industry}

As already mentioned, at the time when the key industrial zone in Mühlau was starting to form, there was no proper regulation to guide new construction. According to architect Eugen Barta, the Chief City Councillor active in the ideas of city regulation and modern urban planning, the first geometric land survey of the city took place between the years 1849 and 1850, and on its basis a position plan by the engineer Miklós Halácsy was created. Barta specifies that this plan contained just some of the regulation of existing streets, and a supplement to the building statute of the city "foresaw the elaboration of a regulation plan, but this imperative command did not happen". ${ }^{41}$ This means that when the first industrial boom occurred, in the 1870s, there was no general plan or detailed vision of the future development of the city that could guide the most effective placement of new factories in a way that would not interfere with future urban growth or pose other problems in the future. Barta goes on to describe a new general land survey that took place in 1894-1895, according to which new maps were produced to scales of $1: 2880$ and 1:1440, but without any contour information about height. In 1909, the City Council commissioned a new regulatory plan from Professor Antal Palóczy from Budapest, which was accepted after series of negotiations in 1917.42

The first attempt to regulate specific areas for industry came, according to published research by architectural historian Henrieta Moravčíková and her colleagues, not from the city, but rather from "an important industrialist from Pressburg, the Director of the First City Savings Bank", Johann Ludwig, who also happened to be a member of

Die Schornstein-Jagd. In: Pressburger Presse, 28. 5. 1900, vol. 3, no. 122, pp. 1-2.

Die Schornstein-Jagd. In: Pressburger Presse, 28. 5. 1900, vol. 3, no. 122, pp. 1-2.

Die Schornstein-Jagd. In: Pressburger Presse, 28. 5. 1900, vol. 3, no. 122, pp. 1-2.

BARTA, Regulácia mesta, 27.

ANDRÁŠIOVÁ et al. Plánované neplánované mesto, 221. 


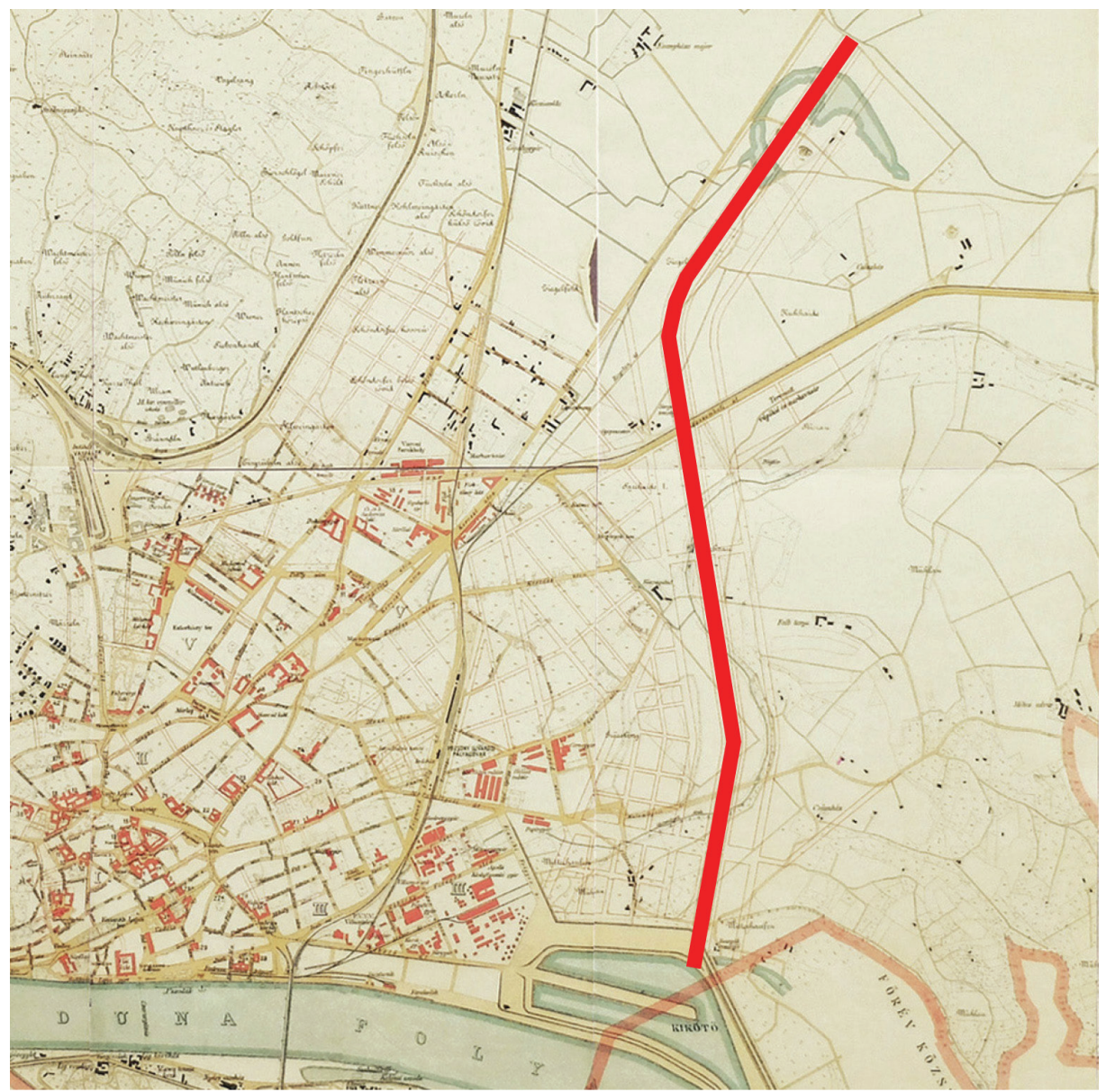

Figure 5: Plan for the regulation and expansion of the city by the City Technical Department from 1906, with red lines representing the industrial channel (highlighted). Source: AMB, Zbierka máp a plánov (Collection of Maps and Plans), no. 1048.

the City Council. ${ }^{43}$ Ludwig had a vision of city development that included construction of an artificial waterway - an industrial canal - that would connect the Danube with the River Váh. A plan based on his ideas, presented in September 1905, was prepared by Royal Counsellor Viktor Bernárdt, the former Commissioner of Hungarian State Railways. Although, according to the authors of the article, the plan was not accepted, among other regulatory issues, it opened up discussion concerning the regulation of an industrial zone to the east of the city. Had it been taken further, it might have helped

43 MORAVČíKOVÁ et al. Červený alebo modrý?, 30-43. 
to extend the discussion about regulation, as the representatives of the city ordered an expert assessment of a regulatory plan designed by its Technical Department. ${ }^{44}$

A copy of the plan for regulation and expansion of the city by its Technical Department from 1906, located by Moravčíková and colleagues in the Széchenyi Library in Budapest, can also be found in the City Archives of Bratislava (Figure 5). However, it was they who first identified the red lines as regulatory directives, including the lines representing the industrial canal. On this plan, the proposed canal follows a "slightly curved line leading from the Winter Harbour northeast, to the Dynamit-Nobel factory and follows the easternmost border of the city". As the authors conclude, the line of the waterway, together with the concentration of industry at the sides of the channel, reflected the intention approved by the City Council in 1905.45

Finally, the city contracted Anton Palóczy, an architect and professor from Budapest (as a follow-up of a request for assessment of the above mentioned plan), to prepare a new regulatory plan in November 1906.46 Though Palóczy worked on the regulatory plan for 10 years, due to the social changes after the First World War it was never accepted in its entirety. As Moravčíková et al. conclude, the city considered neither the plan prepared by its Technical Department in the early twentieth century nor Palóczy's plan binding, and for individual decisions they used whichever one seemed to proposed a more suitable solution. ${ }^{47}$

\section{The Industrial Canal}

Johann Ludwig's idea for an industrial canal was taken seriously: the newly-formed Department for the Promotion of Industry accepted his proposal and agreed to address it at the General Assembly, as stated in an article in the Pressburger Presse. The plan was to start the canal at the second basin of the Winter Harbour, and to lay a broad, navigable channel inland, in the direction of the dynamite factory. The material excavated from the canal bed was to be used to raise the left and right banks, in order to create flood-proof foundations for the factories. A lock (chamber lock) was to be created between the canal and the entrance to the Winter Harbour. ${ }^{48}$ However the proposal, with estimated costs of 600,000 crowns, only considered a segment about $2 \mathrm{~km}$ long, up to Tirnauerstraße (Trnavská Street). The article further specifies that the construction would be a major burden on the city's budget for "about 20 years". The author expresses the opinion that the town would have to take on sacrifices, and that it "should not bleed to death on this project, the benefits of which will only come to future generations". 49

The author of the article assumes that the investment could still be balanced by the favourable location it would create for enterprises, which would be willing to pay the price, but on the other hand, the Trade Minister, Franz Kossuth, should take into account that the canal would go beyond the city's own interests: "as the

44 MORAVČÍKOVÁ et al. Červený alebo modrý?, 35.

45 MORAVČíKOVÁ et al. Červený alebo modrý?, 37.

46 Along with the article from Nyugatmagyarországi hiradó cited by MORAVČíkOVÁ et al. there was also an article published in Pressburger Zeitung (Die Revidierung des Stadtregulierungplanes. In: Pressburger Zeitung, 01. 11. 1906, vol. 143, no. 299, p. 3).

47 MORAVČíkOVÁ et al. Červený alebo modrý?, 35.

48 Der Industriekanal. In: Pressburger Presse, 18. 2. 1907, vol. X, no. 473, p. 1.

49 Der Industriekanal. In: Pressburger Presse, 18. 2. 1907, vol. X, no. 473, p. 1. 
Commission's report rightly points out, it is not merely a local matter for Pozsony, but an excellent means of promoting industry, that is, a national interest. By striving to create ideal foundations for new factories and the conditions of viability of new industries, we are doing a great service to the Government's policy of promoting industry. The request is therefore justified only in so far as it takes on part of the burden arising from that undertaking." 50

As might be expected with such an important matter, it was not accepted unanimously by City Council representatives, even though the majority (65 of 69) agreed with it during a General Assembly of the Municipal Committee held on 18 March 1907. The city's representative and well-known master-builder, Ludwig Eremit, raised a number of doubts regarding the canal. What kind of goods would actually be transported by water? How would the water be provided? What would happen if it froze in the winter? And would it be possible to cross the canal by train? He also expressed concern that the proposed line of the canal would take "the most beautiful, most valuable land", and that the workers' houses would also require more space than Mr Ludwig was claiming. ${ }^{51}$

In the end, the industrial canal was never constructed, probably due to financial difficulties and the First World War that soon followed. After this, industrial planning was again left haphazard for some time.

\section{Modern Planning: Industry in Czechoslovakia}

The establishment of the first Czechoslovak Republic after the First World War brought a radical change for industry in the Slovak sphere. Bratislava, which became Slovakia's capital in 1919, adjusted to the new situation with a "programmatic, pro-Czechoslovak conception". ${ }^{22}$ It was important to deal with the issues of the city's development in order to align with the new situation and increased construction activity. After a short-lived "Regulatory and Art Commission for the city of Bratislava and municipalities of Petržalka and Karlova Ves" (1921-1923) initiated by the Czech and Slovak architects Alois Balán, Klement Šilinger, Josef Marek and Eugen Barta, a special Regulatory Department was established in the years 1924-1925, which proposed the most necessary partial regulations, while preparing conditions for a regulatory plan competition announced in $1928 .{ }^{53}$

It is necessary to note that conditions in the newly established state were not advantageous for local industry. The existing enterprises had been built using foreign capital, with a regard to the large duty-free space of the former Hungary, to which the majority of the market was oriented. Now, Czechoslovakia's direct neighbours were countries which - apart from Romania - had no political inclination towards its government, and were therefore not potential trading partners. In addition to this, Slovak industry had to compete in the newly created state with the stronger Czech industry, which had previously accounted for approximately " $80 \%$ of the industrial potential of the Austrian part of the monarchy". 54

50 Der Industriekanal. In: Pressburger Presse, 18. 2. 1907, vol. X, no. 473, p. 1.

51 Annahme des Antrages bezüglich des Industriekanals. In: Pressburger Zeitung, 19. 3. 1907, vol. 144, no. 77 , p. 3.

52 ŠČEPÁNOVÁ, Vel'ká Bratislava, 89.

53 BARTA, Regulácia mesta, 28.

54 HALLON, Industrializácia Slovenska, 17. HALLON, Miesto a úloha industriálneho dedičstva, 90. 
Nevertheless, for some industrial sectors - such as electrification - the establishment of Czechoslovakia had a positive impact, though this was not a natural outcome of progress, but rather a result of state policy. ${ }^{55}$ The state also tried to amend the situation in industry through a process of so-called "nostrification", an attempt to relocate the headquarters of major companies controlled by capital from Austria and Hungary to the territory of Czechoslovakia, though a number of key companies remained in the hands of foreign capital due to a lack of finance or a lack of interest from domestic investors. ${ }^{56}$ The positive activity of Czech capital manifested itself more noticeably in the economic boom period from 1924 to 1929 that followed the economic crisis (1921-1923). ${ }^{57}$ It is not unreasonable to assume that the difficulties Slovak industry was facing at this time might be connected to why Pressburg was not pressured to relocate its key industrial zone west of the harbour further to the east..$^{58}$

The first city regulatory initiative in the interwar period came from the architect Dušan Jurkovič, who headed the government Commission for Heritage Protection in Slovakia. The architectural historian Soňa Ščepánová points in her recent research to an article by Dušan Jurkovič in the bi-monthly magazine Nová práce, where he talks about the option to build a high-rise city quarter as a counterweight to the castle, consisting of "department stores, hotels and residential buildings of even 12 to 15 stories high, or even skyscrapers as a closed entity, designed as one architectural unit". ${ }^{59}$ From Jurkovič's vague description of the quarter's location "on the east side, perhaps between the Danube River and the future main railway station", which is not further accompanied by any plan to identify the position of the railway station, we can only guess whether his bold proposal overlapped with the currently exiting high-rise quarter in the former key industrial zone. ${ }^{60}$ Though at the time opinions regarding the main railway's location varied, Jurkovič writes in an earlier article published in the newspaper Slovenský denník that it should be located in the area between Blumental church and the dynamite factory. ${ }^{61}$ This means that "his" high-rise quarter would likely have been further north from the river than the current projects of both Panorama City and Twin City.

Jurkovič highlighted the importance of a good rail connection with the harbour, and he believed that the construction of the new railway station should be undertaken at the same time as the Winter Harbour as they - together with Devin Castle and Bratislava

55 HALLON, Industrializácia Slovenska, 61.

56 In Bratislava, this concerned the textile industry and the electric transport company (HALLON, Industrializácia Slovenska, 51).

57 HALLON, Industrializácia Slovenska, 68-69.

58 The Czech capital city Prague, on the other hand, according to an article published in magazine Nová práce, noted the importance of locating industry as far as possible to the east, and planned an industrial city according to the newest modern principles, particularly those from America. (ZÁKREJS, Cesta k organisaci průmyslu).

59 JURKOVIČ, Stavební otázky, 17-20.

60 Even though Ščepánová locates the high-rise zone on the riverbank, in reality Jurkovič might have thought about an area further north. The confusion is caused by a presumed typographical error in the original text, where the word "hlavní nábřeží" (main riverbank) should be rather "hlavní nádraží" (main railway station) as in: JURKOVIČ, Stavební otázky, 17.

61 Vel'ká Bratislava. Rozhovor s architektom Jurkovičom, vládnym komisárom. In: Slovenský denník, 3. 10. 1920, vol. 3, no. 225, pp. 1-2. 
Castle - were the common pillars of the single building of "The Great Bratislava". ${ }^{2} \mathrm{He}$ did not further address the question of which zones the industry should ideally occupy. Regarding workers' housing, he believed that Slovak workers were too connected to a rural kind of life, and should therefore be located near Dynamitka, on the left side of the road to Rača, while "the sites on the right side of the road before the dynamite factory and behind it by the railways must be reserved for industrial enterprises". ${ }^{63}$

Even though industry in general faced challenging times, Bratislava, according to the architect Balán, was intended to become a "hub of central European commerce", ${ }^{64}$ for which the Danube River and harbour became crucial. It was expected that in connection to the harbour, an adjacent area of suitable size would be created, with appropriate functions to support all the harbour's needs. ${ }^{65}$ With the new political situation, Bratislava harbour was ready to be developed, as the regulation of the Danube River had already been completed and the Winter Harbour was constructed. ${ }^{66}$ As boat transport was cheaper than railway transport, in general it made sense to locate industrial buildings in the proximity of the harbour. ${ }^{67}$ Accordingly, most of the reproduced regulatory proposals submitted for the competition of 1929 (the original plans were not available) locate the industrial zone in connection to the harbour. ${ }^{68}$

Even though the winning proposal, designed by architects Dryák and Tvarožek, was approved in $1933,{ }^{69}$ with regard to the industrial planning tackled by this study, it is the proposal by architects Alois Balán, Jiří Grossmann and Arnošt Suske - awarded third place (or in fact second, as first place was not awarded) - that seems especially important (Figure 6). Out of the few known proposals, it seems to be the only one that thought of moving the key industrial zone out of its existing placement toward the southeast. While it would still be adjacent to the harbour, the proposal freed the area for inner-city type construction of either high-rise (meaning four stories at the time) or mid-rise buildings. ${ }^{70}$

62 Vel'ká Bratislava. Rozhovor s architektom Jurkovičom, vládnym komisárom. In: Slovenský denník, 3. 10. 1920, vol. 3, no. 225, pp. 1-2.

63 Jurkovič considered the proposed workers' living area healthy, as the wind would blow the smoke to the Danube and beyond. See: Vel'ká Bratislava. Rozhovor s architektom Jurkovičom, vládnym komisárom. In: Slovenský denník, 3. 10. 1920, vol. 3, no. 225, pp. 1-2.

64 BALÁN, Regulácia a výstavba mesta Bratislavy, 1.

65 There was no interest in developing the area during the Austro-Hungarian Empire, as the monarchy was more interested in developing harbours in Vienna and Budapest, where the main railways were centred.

66 HABERLANDOVÁ - KALOVÁ, Prístav v Bratislave, 59.

67 HROMÁDKA, Zemepis okresu bratislavského a malackého, 24.

68 Images from Architektura ČSR (1958, vol. XVII, no. 1, 11-7) with an overlay highlighting the industrial zone were published in: BARTOŠOVÁ, Fading industrial heritage, 105-112.

69 ANDRÁŠIOVÁ et al. Plánované neplánované mesto, 221.

70 In comparison to the plan published by Ščepánová (ŠČEPÁNOVÁ, Vel'ká Bratislava, 99), the proposal printed in Hromádka (HROMÁDKA, Zemepis okresu bratislavského a malackého) shows a slightly different copy, showing a larger area, accompanied by a legend (unfortunately in black and white, therefore some of the functions are not legible). 


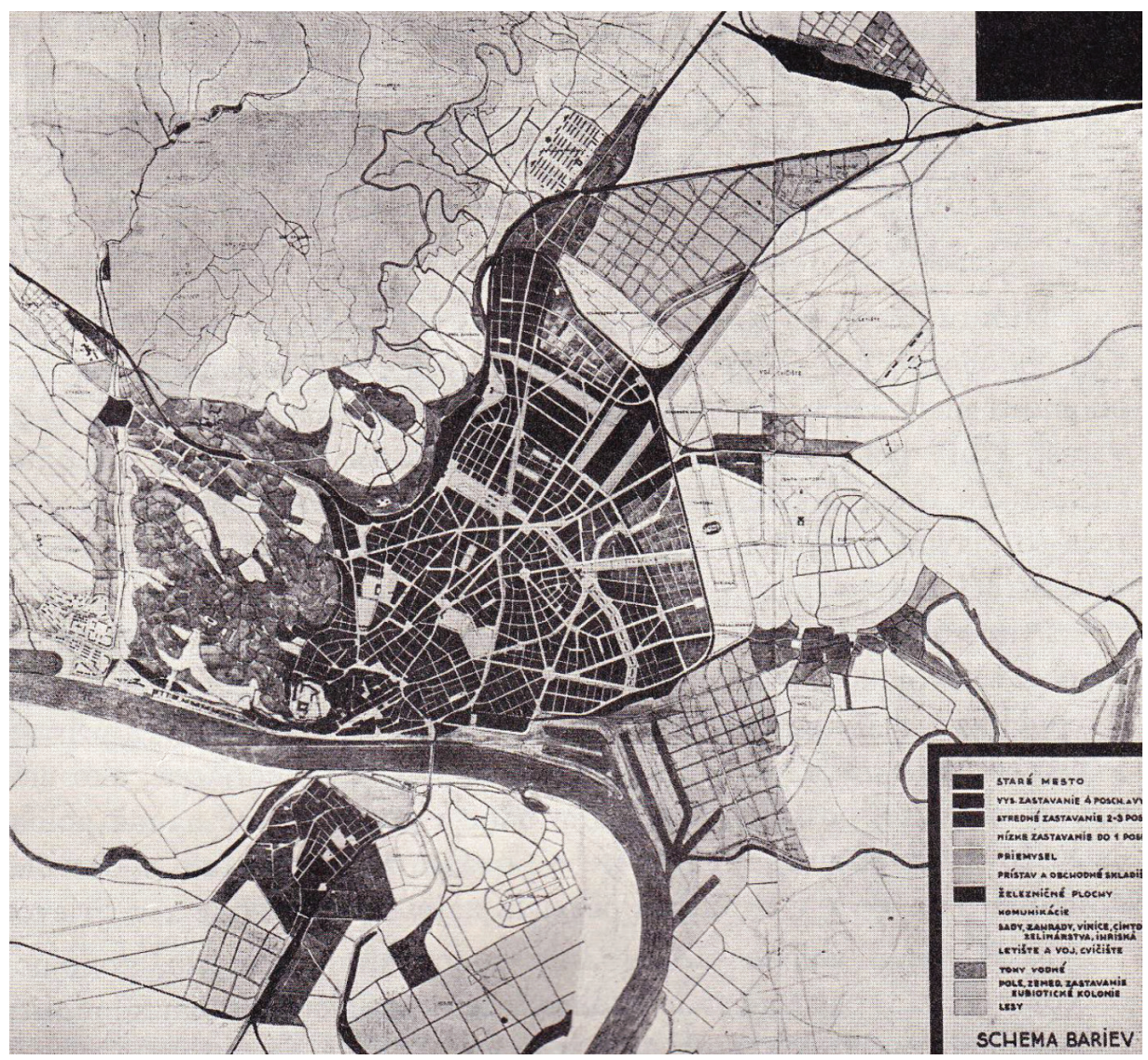

Figure 6: Regulation plan proposal by the architects A. Balán, J. Grossmann and A. Suske from 1929. Source: HROMÁDKA. Zemepis okresu bratislavského a malackého, 77.

\section{Regulation Battling with Private Interests}

Even before the city had an approved regulatory plan, the city authority was trying to focus industrial production in a designated area via partial regulations. For example, in 1926, the Technical Department's proposed widening of important roads north of the key industrial area had been approved (Oberufer Road and Feriby Road, now Mlynské nivy and Prievozská Street)..$^{71}$ Around that time, a regulation issued by the City Council on 13 April 1926 and approved by the Regional Authority on 7 February 1928 declared that all the lots south of this road should be reserved exclusively for industrial and commercial uses, and lots on the north side could be developed with mixed industrial and commercial enterprises and also residential buildings, "provided that the mixed

71 Proposed in 1925 by the Technical Department, approved in April 1926: the road with regulatory lines $10 x$ 10 meters on both sides from the axes, would start at the Helle factory toward Feriby (now Prievoz), according to the Technical Department. The new building heights on this street - either solitary or as complex of buildings would have had a maximum of three stories, $12.0 \mathrm{~m}$ in height (AMB, ÚHA, Regulácie, Box no. 842). 
construction responds to the interests of public safety and good taste"..$^{22}$ The idea was to concentrate industry below Oberufer and Feriby Roads and further to the east, therefore it was determined that the municipality of Prievoz (Feriby in Hungarian, Oberufer in German) should analogously designate an industrial zone in its area. ${ }^{73}$ There was another a proposal, also supported by the Port Shipping Authority (Poriečny plavebný úrad), to change the cadastral boundaries of Feriby, as Warehouse no. 17 was no longer in the area of Bratislava. However, the matter was too complicated to deal with at the time, and the municipality of Prievoz did not became part of the Bratislava until 9 March 1945, as District XV of Greater Bratislava. ${ }^{74}$

While the regulatory plan was further amended in 1932, due to the need to build a parallel road to the Winter Harbour, from Ludwig Road (now Košická) to the new gasworks (Prístavná ulica), such changes did not interfere with the general idea. Paradoxically, what actually blocked, or at least slowed down, the pursuit of a designated industrial zone were the individual interests of private owners of specific lots. Documents available in the City Archives of Bratislava illustrate how individual controversies affected big decisions regarding industry.

For several years, a dispute between the city and Knechtsberger Company affected the process of setting clear boundaries for Bratislava's industrial zone. The Knechtsberger Company did not agree with the city's decision to dedicate all areas south of Feriby Road to industry, proposing to reduce the industrial area, as their interest was in erecting residential buildings. ${ }^{75}$ At that time (1934), the City Council decided not to issue a regulatory plan for the area, but, for the time being, to subdivide it into allotments for gardening. However, the Regional Authority advised the City Council not to divide the Knechtsberger Company area into small parcels, "as previous experience suggests that it leads to illegal construction activity by the socially weakest classes in a manner completely inadequate in terms of hygiene and construction principles and regulations".

Meanwhile, on 15 April 1937, the City Council accepted a proposal from the Regulatory Advisory Board to enlarge the harbour and its industrial zone (Figure 7), and stabilised the industrial area in the southeastern part of the city (according to a map to the scale of 1:5000). At the same time the City Council of Prievoz was asked to approve the proposal and take it into account regarding its cadastral area, so that the area to a distance of about 900 meters from the left bank of the Danube toward the east would become an extension of the Winter Harbour and the establishment of an adjacent industrial area. Also, the National Railway Directorate in Bratislava was requested to make a proposal for planned railway facilities for the city available. ${ }^{76}$

72 AMB, ÚHA, Regulations, Box no. 842 (letter from the Representative body, 12 April 1926).

73 Bordered by the Little Danube on the south; by the great Danube River on the west; by the common border between the municipalities of Bratislava and Feriby, from the Danube river up to the southeast tip of the Bratislava cadastre to site no. 12124; by the mentioned site on the east; and extending to northeast up to the Little Danube. As in: AMB, ÚHA, Regulations, Box no. 858.

74 Together with Račišdorf/Rača, Vajnory, Lamač and Dúbravka. Vel'ká Bratislava skutkom. In: Gardista, 10. 3. 1945, vol. VII, no. 56, p. 3. Prievoz pripojili k Vel'kej Bratislave. In: Gardista, 29. 3. 1945, vol. VII, no. 71, p. 3.

75 The plan was such that the eastern border would be defined by a road "from Oberufer Road to a road underpass at the east of the projected harbour railway station and through the sandbanks (piesčiny) toward the small Danube, while the area to the east of this road could be designated for residential building, although no infrastructure would be provided in a foreseeable period." As in: AMB, ÚHA, Box no. 858.

76 AMB, ÚHA, Box no. 858. 


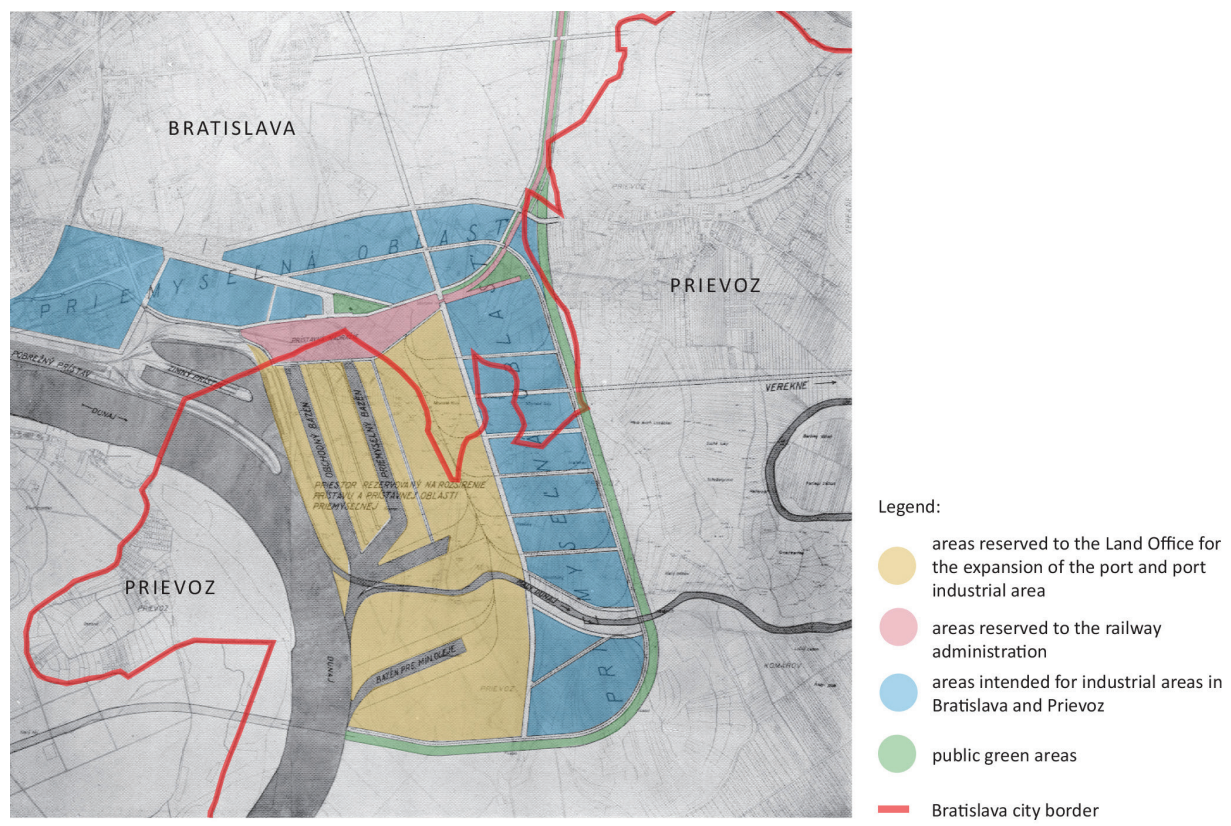

Figure 7: Proposal for harbour enlargement and its industrial zone. The coloured areas are applied according to the regulation documentation for the "stabilization of the industrial area of Bratislava's port". Source of data: MOLINEK, Robert. Komunikačné otázky mesta Bratislavy. In: Slovenský stavitel', 1936, no. 9, p. 263, AMB, ÚHA, Regulácie, box no. 858.

It was planned that the main street of the industrial area - which was also to be the main peripheral road of the city - would be $30 \mathrm{~m}$ wide, and that it would lead as straight as possible from the end of the proposed cargo station, smoothly passing under the eastern part of the cargo station, then proceed straight toward a proposed bridge over the Little Danube, north of the Vlčie hrdlo area. Along the peripheral road, a 50 metre-wide green belt was proposed for health reasons, to separate the area from adjacent residential areas, and leave open the option to build bypasses (railways, roads) in the future. ${ }^{77}$

The Regional Authority stated, on 21 July 1937, that the existing regulation of the enlargement of the industrial zone of the Bratislava harbour, approved on 15 April 1937 according to the public interest, had been changed "to the detriment of public interest", apparently solely from a private (profit-driven) initiative that was, above all, interested in the sale of the subdivided area. In the end, it seems that private interests prevailed, or at least managed to halt the original plan. Even though, on the 12 May 1938, the Regional Authority decided to reject the proposal to subdivide the lots into allotments for gardening, on 23 May 1938, the Regional Authority recommended that the City Council should reduce the eastern border of the industrial zone and limit it to the planned road from Oberufer Road toward an underpass planned for the eastern part of the future harbour railway station.

77 MOLINEK, Komunikačné otázky, 274. 


\section{From Key Industrial Zone to New High-Rise Quarter}

Although there were other attempts to limit industry to specific areas even after the Second World War, ${ }^{78}$ we have not found any mention that would render the industrial zone that we focus on in this research especially problematic. After 1948, the former regulatory plans were replaced by "more complex tools in the form of urban studies and land-use plans"..$^{79}$ The changes in the focus area came later, after the fall of socialism in 1989, when social and economic changes led to a large sell-off of previously city-owned land and properties to private owners. The new development that arose during the resulting real-estate and construction boom was, according to architectural historians Moravčíková and Szalay, "the outcome of a trajectory changing the post-socialist city into a global and capitalist one". ${ }^{\circ 0} \mathrm{It}$ is those private subjects that still in reality control "all of the central development areas for Slovakia's cities". 81

The financial crisis of 2008 did not change this situation, rather merely holding up new construction, but in the meantime, it facilitated the demolition of a number of industrial complexes. The privatisation of former industrial sites by private investors reflected their financial interests; not only were they mostly ignorant when it came to discussions of the buildings' heritage value, but they actively evaded processes established by law. Regarding our focus area, $80 \%$ of the Apollo refinery was destroyed during bombardment by the Allied forces on 16 June 1944, but on the premises of the Kablo factory, a historical boiler house (in the process of being listed and, therefore already protected) was torn down in January $2008 .{ }^{82}$ In July of the same year, a listed 1911 building that was part of the Gumon factory was torn down and, as was the case with Kablo, the investor managed to avoid paying a fine. ${ }^{83}$

As urban geographer Pavel Šuška further comments, interest in new economic uses of former industrial areas naturally rises with the decay of industrial production. ${ }^{84}$ Shifts in the economy towards the service sector, and the attractiveness of centrally located positions within the city for new construction, made the historical industrial areas valuable to investors. At present, the complete transformation of our zone of focus is nearing completion. Apart from a few historical objects remaining from the industrial era - such as the two storey building on No. 10 Továrenská Street (formerly part of the Klinger factory, later taken over by Apollo), the power plant designed by the important Slovak architect Dušan Jurkovič from the 1940s, and Design Factory (formerly part of Apollo), whose future is unclear in the moment, and a few other structures - this area is now characterised by the high-rise residential tower designed by Zaha Hadid Architects and the Twin City office complex on the premises of the Kablo factory.

While changes in the area's function might have been unavoidable and even positive - we have questioned the appropriateness of industrial production in the neighbourhood of the city in this study - the motivations behind the processes, subordinated to individual economic interests and with disregard for the "higher

78 See, for example, the development plan proposed by Kamil Gross (Zastavovací plán 1949) or the regional plan submitted by Ján Svetlík (Územný plán 1954). As in: ŽALMAN, Urbanistický atlas Bratislavy, Sheet 5.

79 ANDÁŠIOVÁ et al. Plánované neplánované mesto, 217.

80 MORAVČÍKOVÁ - SZALAY, Problémy navrhovania a výstavby, 13.

81 MORAVČíKOVÁ - SZALAY, Problémy navrhovania a výstavby, 16.

82 ŠUŠKA. Historické priemyselné štruktúry, 255. See also: ŠUŠKA, Aktívne občianstvo, 102.

83 ŠUŠKA, Historické priemyselné štruktúry, 255.

84 ŠUŠKA, Historické priemyselné štruktúry, 255-256. 
good" of public interest, are clearly problematic. Demolition and new construction were pushed by investors, whose decisions were not based on any expert studies or in-depth research evaluating whether such high-rise structures were at all desirable in the area. In addition, work on the foundation of new development on the adjacent site of the Panorama City towers in 2013 uncovered a large oil lake: residue from the former Apollo Oil Refinery. The smell of oil was also present while the foundations for Zaha Hadid's Sky Park were excavated, and even though the area was decontaminated during construction, the problem remains, as the deep-laid concrete structures pushed the contamination further - that is, closer to the city. ${ }^{85}$

Though the future of our focus area is already almost completely planned, with the exception of uncertainty relating to individual buildings (such as the already mentioned Design Factory), knowledge from past experiences might be very useful in relation to the adjacent area of the Winter Harbour in the near future. Although there have been few ideas proposed as to how to use the area - the most visible ones being by investors and their architects - definite decisions that will determine its future are still pending. Thanks to the fact that it is still operating in its original function, to a certain extent, the area has not seen the same kind of rushed demolition with ambiguous intentions described above, and the Monument Board of the Slovak Republic has succeeded in listing several buildings in the harbour premises: the River Transport Authority building from the 1940s (Dom lodníkov, listed in 2008), the tugboat Šturec (2011), a boat workshop and the ship lift (2015). Several other warehouses on the site (No. 14,16 , and 17) are still in the process of becoming listed. ${ }^{86}$ What will be an issue in the harbour area, as it was in the zone of the former Apollo factory, are the legal aspects.

Again, as in most former industrial sites, the harbour premises are not city properties. This does not necessarily mean that the city has no legal tools to influence the result, but it is more difficult, and it might take more time to apply the necessary strategies. This can be advantageous for an owner/investor ready to act promptly to carry out their intentions, carrying with it the risk of irreplaceably destroying some of the architectural heritage as well as environmental or spatial values. Reuse of large industrial areas is a difficult challenge, requiring not only financial resources, time and expertise, but, most of all, the willingness to initiate an open discussion among all the various stakeholders involved in the decision-making process or otherwise affected by its results. ${ }^{87}$

\section{Conclusion}

As far as our research shows, the area that is now defined by the streets Mlynské nivy, Dostojevského rad, Karadžičova, Košická and Landererova became the city's key industrial zone not as a result of strategic planning of premeditated decisions, but rather through a series of individual circumstances. In each of these situations, industrial development in the area seemed reasonable and beneficial. Even among existing publications, we have not seen any that would question this decision. To the contrary, they supported the argument that the area, as a peripheral zone with the advantage

85 DUGOVIČ, "Bratislavskí developeri stavajú mrakodrapy na rope", Denník N. Accessed 10 December 2017. https://dennikn.sk/965678/bratislavski-developeri-stavaju-mrakodrapy-na-rope-toxicke-latky-sa-z-apollkysiria-podzemim-mapy/

86 BARTOŠOVÁ, Waterfronts as Integral Part of Cities, 660.

87 See more in: BARTOŠOVÁ - HABERLANDOVÁ, Industriál, 56-60. 
of the Danube and railways connections, was naturally the best option, and the issues encountered later were a result of the growth of the inner city.

However, this study indicates that the decision was questioned, even during the "heroic times of industry". ${ }^{88}$ In fact, while some of the motives were reasonable - such as the need for good transport connections and consideration of the prevailing winds others, such as allowing somewhat dangerous heavy industry (Apollo, and later also the Gumon enterprise, established as a part of the cable factory), were choices that were most probably driven by private interests. Once established, a much greater effort would be required to move industry from this zone to areas further from the city. The Apollo Oil Refinery, benefiting from its strong position as "an important enterprise for state interests" throughout various political regimes (Austria-Hungary, interwar Czechoslovakia and even the Slovak Republic under the Nazi regime) defined the character of the zone.

The political and social changes triggered by the fall of socialism in 1989 again brought forth a desire for individual subjects' economic profit. Although the stakes were now different, they again acted at the expense of generally beneficial solutions that would focus on society as a whole, and a more sustainable development of those zones in the context of the entire city. In most cases, appropriate procedures that could have ensured a proper evaluation of the industrial structures, their heritage value and their conservation were omitted, or not satisfactorily applied. Therefore, instead of seeking the best ways to repurpose or adapt these buildings, many of them were demolished.

While we think it is important to focus on protection of individual structures, their heritage values and potential for further use, ${ }^{89}$ what could be beneficial in the quest for a solution is a fuller understanding of a situation, whether past or present. The issue of protecting industrial structures in Bratislava is closely connected to the history of planning, not just regarding the localities where they were built, but also regarding what kind of industry is allowed to be established around a city. A failure to take not of the negatives from the past regarding planning will inhibit society's understanding of the complexity of the topic. On the other hand, a better understanding of the issue's complexity - seeing a bigger picture - might also help heritage experts to enter the necessary discussion with a more open mind and propose solutions that are sustainable.

While there has been a slight shift in the situation in recent years, and several buildings have been listed and repurposed for modern use, heritage values still represent more of a burden then an asset for owners/developers. Although they sometimes refer to the historical background of industrial sites, this comes not from a deep understanding and respect for cultural values, but rather more as means to commercially promote their investment projects with a well-known name. Hence, those positive examples of conserved industrial buildings incorporated into new developments do not really represent a reliable outcome of successful protection of heritage in the country, but are mere fragments of conservationists' efforts in the struggle to protect at least some of the structures from being erased from the fabric of the city. A more visible change will not occur until there is a stronger will among the parties representing different values to participate in mutual discussion driven by a common aim to benefit both the larger society and the environment.

88 Term used by HROMÁDKA, Zemepis okresu bratislavského a malackého, 92.

89 Demolition should be seen as the last option, after all other possibilities have been examined. 


\section{BIBLIOGRAPHY}

AMB, Zbierka máp a plánov (Collection of Maps and Plans)

Arcanum Database Ltd.

Hungarian Digital Archive of Pictures, http://keptar.oszk.hu

Slovnaft Archive

RAINER, Rudolf - ULREICH, Eduard. Karpatendeutsches Biographisches Lexikon.

Arbeitsgemeinschaft Karpatendeutscher Familienforscher. http://www.agkff.de/index. php?title=Carl_Grüneberg\&oldid=274

Staré mapy. https://www.staremapy. sk/?zoom=15\&lat=48.143244177375166\&lng=17.12604831793362\&map=Bratislava1873

A pozsonyi kereskedelmi akadémia. In: Nyugatmagyarországi hiradó, 6. 10. 1897, vol. X, no. 228 , p. 3 .

Annahme des Antrages bezüglich des Industriekanals. In: Pressburger Zeitung, 19. 3. 1907, vol. 144 , no. 77 , p. 3.

Der Industriekanal. In: Pressburger Presse, 18. 2. 1907, vol. X, no. 473, p. 1.

Der Schluss der vorgestrigen Repräsentanten-Sitzung. In: Pressburger Zeitung, 5. 11. 1897, vol. 134 , no. 306, p. 2.

Die Revidierung des Stadtregulierungplanes. In: Pressburger Zeitung, 01. 11. 1906, vol. 143, no. 299 , p. 3.

Die Schornstein-Jagd. In: Pressburger Presse, 28. 5. 1900, vol. 3, no. 122, pp. 1-2.

Erasmus Hafenlauf stellt darüber Betrachtungen an, wie spät oft manchmal die Erleuchtung kommt. In: Pressburger Zeitung, 17. 5. 1891, vol. 128, no. 135, p. 5.

Hirdetmény. In: Nyugatmagyarországi hiradó, 8. 8. 1895, vol. 8, no. 181, p. 2.

Neue Arbeiterhäuser. In: Pressburger Zeitung, 14. 1. 1894, vol. 131, no. 12, p. 2.

Noch einmal die "liebliche" Mühlau. In: Pressburger Zeitung, 25. 11. 1894, vol. 131, no. 323, p. 2.

Prievoz pripojili k Velkej Bratislave. In: Gardista, 29. 3. 1945, vol. VII, no. 71, s. 3.

Tagesneuigkeiten. In: Pressburger Zeitung, 4. 1. 1883, vol. 119, no. 3.

Velká Bratislava skutkom. In: Gardista, 10. 3. 1945, vol. VII, no. 56, p. 3.

Velká Bratislava. Rozhovor s architektom Jurkovičom, vládnym komisárom. In: Slovenský denník, 3. 10. 1920, vol. 3, no. 225, pp. 1-2.

Von der "schönen" Mühlau. In: Pressburger Zeitung, 24. 11. 1894, vol. 131, no. 322, p. 2.

Zum Bau von Arbeiterwohnungen in der Mühlau. In: Pressburger Zeitung, 14. 11. 1894, vol. 131, no. 312 , p. 2.

ANDRÁŠIOVÁ, Katarína - DULLA, Matúš - HABERLANDOVÁ, Katarína MORAVČÍKOVÁ, Henrieta - PASTOREKOVÁ, Laura - SZALAY, Peter. Plánované neplánované mesto: Moderné urbanistické koncepcie v tradičnej mestskej štruktúre [Planning the Unplanned City: Modern Urban Conceptions in a Traditional Urban Structure]. In: Architektúra \& urbanizmus, 2015, vol. 49, no. 3-4, pp. 216-239.

BALÁN, Alois. Regulácia a výstavba mesta Bratislavy. In: Slovenský denník, 13. 1. 1921, vol. IV, no. 9, p. 1.

BARTA, Eugen. Regulácia mesta. In: Bratislava hlavné mesto Slovenska. Pressburg: Hauptstadt der Slowakei, 1943, pp. 23-36.

BARTOŠÍKOVÁ, Tereza. Prístav v Bratislave - srdce obchodu. In: Monument revue, 2018, vol. 7, no. 2, pp. 22-31.

BARTOŠOVÁ, Nina. Fading industrial heritage of Bratislava in the urban planning context. In: SGEM 2018: 5th International Multidisciplinary Scientific Conference on Social Sciences and Arts. Conference proceedings. Vol. 5. Urban Planning, Architecture and Design, Vienna, 19-21 March 2018. Sofia: STEF 92 Technology, 2018, pp. 105-112.

BARTOŠOVÁ, Nina. Waterfronts as Integral Part of Cities: Adaptation and Re-Use of Harbour's Industrial Heritage in Bratislava. In: SGEM 2019: 6th International 
Multidisciplinary Scientific Conference on Social Sciences \& Arts. Conference Proceedings. Vol. 6 Science \& Arts. Sofia: STEF92 Technology, 2019, pp. 657-664.

BARTOŠOVÁ, Nina - HABERLANDOVÁ, Katarína. Industriál očami odborníkov / pamätníkov [Industrial heritage in the eyes of expertise/experience]. Bratislava: Vydavatelstvo STU, 2016.

BIANCHI, Leonard. Zákonodarstvo a vývoj priemyslu v Uhorsku za dualizmu (1867-1918). In: Právněhistorické studie, 1973, vol. 17, pp. 113-144.

BOROVSZKY Samu (ed.). Magyarország vármegyéi és városai. Pozsony vármegye. Budapest, 1904.

DUGOVIČ, Matej. “Bratislavskí developeri stavajú mrakodrapy na rope”, Denník N. Accessed December 10, 2017. https://dennikn.sk/965678/bratislavski-developeri-stavaju-mrakodrapyna-rope-toxicke-latky-sa-z-apollky-siria-podzemim-mapy/

HABERLANDOVÁ, Katarína - KALOVÁ, Petra. Prístav v Bratislave. In: Pamitaky \& múzeá, 2015 , vol. 64 , no. 1 , pp. 59-63.

HALLON, Ludovít. Firma Pittel a Brausewetter v dejinách Slovenska. Priekopník betónového stavitelstva $z$ Bratislavy. Bratislava: Historický ústav SAV, 2014.

HALLON, Ludovít. Industrializácia Slovenska 1918-1938: (Rozvoj alebo úpadok?). Bratislava: Veda, 1995.

HALLON, Ludovít. Miesto a úloha industriálneho dedičstva v dejinách priemyslu - na príklade firmy Pittel a Brausewetter. In: KRÁL'OVÁ, Eva. Stopy priemyselného dedičstva na Slovensku. Bratislava: Slovenská technická univerzita v Bratislave, 2010, pp. 82-97.

HALLON, Ludovít. Význam industrializačnej politiky Uhorska pre technický vývoj na Slovensku v období druhej priemyselnej revolúcie 1867-1918. In: Historické štúdie: ročenka Historického ústavu Slovenskej akadémie vied, 2013, vol. 47, pp. 121-148.

HORVÁTH, Vladimír. Bratislavský topografický lexicon. Bratislava: Tatran, 1990.

HROMÁDKA, Ján. Zemepis okresu bratislavského a malackého. Volume 1. Bratislava: Nákl. učitelstva, 1933.

IŽO, Augustín. Dejiny Apolo rafinérie - predchodcu n. p. Slovnaft 1895-1945: Tabulky a prílohy. Bratislava: Slovnaft, 1974.

JURKOVIČ, Dušan. Stavební otázky velké Bratislavy. In: Nová práce, 10. 4. 1921, vol. III, no. 2 , pp. 17-20.

KAČÍREK, Luboš - TIŠLIAR, Pavol. Petržalka do roku 1918. Bratislava: Muzeológia a kultúrne dedičstvo, o. z., 2014.

KÖNYÖKI, Jozef. Kleiner Wegweiser Pressburg's und seiner Umgebung. Pressburg: Selbstverlag des Comité's, 1873.

KUBÁČEK, Jiří. Uhorská centrálna železnica. In: KUBÁČEK, Jiří et al. Dejiny železníc na území Slovenska. Bratislava: ŽSR, 1999, pp. 35-36.

MOLINEK, Robert. Komunikačné otázky mesta Bratislavy. In: Slovenský stavitel', 1936, no. 9, pp. 272-274.

MORAVČÍKOVÁ, Henrieta - LOVRA, Éva - PASTOREKOVÁ, Laura. Červený alebo modrý? Začiatky moderného plánovania Bratislavy [Red or Blue? The Start of Modern Planning $\mathrm{n}$ Bratislava]. In: Architektúra \& urbanizmus, 2017, vol. 51, no. 1-2, pp. 30-43.

MORAVČÍKOVÁ, Henrieta - SZALAY, Peter. Problémy navrhovania a výstavby vo vzt̉ahu k súčasnému slovenskému mestu [Problems of Designing and Construction in Relation to the Contemporary Slovak City]. In: Ročenka slovenskej architektúry, 2016/2017. Bratislava: Slovart, 2018, pp. 6-27.

OBUCHOVÁ, Viera. Najstaršie továrne Bratislavy alebo základný výskum technických pamiatok Bratislavy z hladiska pamiatkovej starostlivosti. In: Technické pamiatky Bratislavy: Zborník Mestskej správy pamiatkovej starostlivosti a ochrany prírody v Bratislave. Bratislava: Mestská správa pamiatkovej starostlivosti a ochrany prírody, 1985, pp. 17-26.

OBUCHOVÁ, Viera. Priemyselná Bratislava. Bratislava: Marenčín PT, 2009.

Pallas Lexikon [A Pallas nagy lexikona]. Budapest, 1895.

PIŠÚT, Peter. Využitie historických krajinomalieb na rekonštrukciu regulačných prác v koryte rieky - príklad Dunaja v Bratislave. In: Geographia Cassoviensis, 2008, no. 2, pp. 173-194. 
POHANIČINOVÁ, Jana. Tvorba Feiglerovcov v ére rozvoja priemyslu a dopravy - moderná architektúra svojej doby. In: KRÁLOVÁ, Eva (eds.). Stopy priemyselného dedičstva na Slovensku. Bratislava: STU, 2010, pp. 110-115.

POHANIČOVÁ, Jana - BUDAY, Peter. Storočie Feiglerovcov. Bratislava: Trio Publishing, 2015. STANISLAV, Ján. Rafinéria Apollo v perimetri dokumentov: súvislosti a dôsledky bombardovania 16. júna 1944. Banská Bystrica: Múzeum Slovenského národného povstania, 2017.

ŠČEPÁNOVÁ, Soňa. Velká Bratislava architektov Aloisa Balána a Jiřího Grossmanna [The greater Bratislava of architects Alois Balán and Jiří Grossmann]. In: Architektúra \& urbanizmus, 2019, vol. 53, no. 1-2, pp. 88-102.

ŠPIESZ, Anton. Manufaktúrne obdobie na Slovensku 1725-1825. Bratislava: Slovenská akadémia vied, 1961.

ŠULCOVÁ, Jana. Historický industrial - "stopa budúcnosti”. In: DVOŘÁKOVÁ, Viera (ed.). Monumentorum tutela. Ochrana pamiatok 20. Bratislava: PÚ SR, pp. 338-343.

ŠUŠKA, Pavel. Historické priemyselné štruktúry v meniacej sa mestskej krajine Bratislavy. In: Geografický časopis [Geographical Journal], 2019, vol. 71, no. 3, pp. 241-262.

ŠUŠKA, Pavel. Aktívne občianstvo a politika premien mestského prostredia v postsocialistickej Bratislave. In: Geographia Slovaca 29. Bratislava: Geografický ústav SAV, 2014, pp. 1-145.

SZOJKA, Ladislav. Bratislava a železnice: železnice v Bratislave do roku 1918. Bratislava: HMH, 2011.

ZÁKREJS, Vladimír. Cesta k organisaci průmyslu. In: Nová práce, 15. 9. 1922, vol. IV, no. 18, pp. 169-173.

ŽALMAN, Peter. Urbanistický atlas Bratislavy. Bratislava: GDA Visual, 2016. 